\title{
Patient Questionnaire
}

If you have already completed this form, please do not complete it again.

1) Race/ethnicity: (please check all that apply)

American Indian or Alaska Native

Native Hawaiian or Pacific Islander

Asian

White

Black or African American

Other or unknown

2) Are you Hispanic or Latinx?

$\square$ Yes $\quad \square$ No

3) Age: __ years old

4) Sex: $\square \mathrm{M} \quad \square \mathrm{F}$

5) At this time, at Penn Behavioral Health, what services are you receiving?

$\square$ Medication management $\quad \square$ Talk therapy $\square$ Both

6) Are you interested in receiving talk therapy at this clinic?

$\square$ Yes $\quad \square$ No

7) Do you own a smartphone? "Smartphones" are phones that can use your location (GPS), download apps, and connect to the Internet.

$\square$ Yes $\quad \square$ No

If yes: Is your smartphone apple or android?

Apple (iPhone)

Android (Samsung Galaxy, HTC, Motorola, etc.)

If yes: Is your phone in good working condition? Please check "No" if your phone is frequently shut off by the phone company, or if your phone does not work well (e.g. if your phone does not turn on or if your screen is too difficult to read due to cracks).

$\square$ Yes $\quad \square$ No

8) Do you usually have your phone with you when you leave home?

Yes - I almost never leave my house without my phone.

In between - I leave my house without my phone about half the time.

No - I often leave my house without my phone.

9) Do you use your phone as an alarm clock to wake up?

$\square$ Yes $\quad \square$ No

10) Do you look at your phone before bed?

11) When you wake up?

$\square$ Yes $\quad \square$ No

Yes

No

12) How do you use your phone for communicating with family, friends, or for work? Please check all that apply.

Phone calls

Texting

Facebook

messenger
Google chat

Kakao talk

WhatsApp

WeChat 


\section{Patient Questionnaire}

13) Which social media do you use? Please check all of the social media that you post/comment/interact on, and circle your one favorite social media.

$\square$ ask.fm

Facebook

$\square$ Tumblr

Instagram

musical.ly

$\square$ Twitter

$\square$ Pinterest

YouTube (only select if you

reddit

$\square$ SnapChat

I do not use any social media

14) What do you post on social media? Please check all that apply.
Photos
Videos
Links (to articles, videos, other peoples' posts, etc.)
My mood/feelings
Opinions or personal recommendations
$\square$ Reactions (to news, events, other people, etc.)
Important life updates
Everyday things that happened in your life
Activities
Goals/plans for the future
Comments/ "likes" of other posts
Other
I never post anything on social media

15) Would you be willing to share your social media posts (e.g. Facebook, Twitter, Instagram, etc.) with your therapist if your therapist was concerned about how you were doing?

$\square$ Yes $\quad \square$ No

If yes: What social media content would you be willing to share with your therapist?

$\square$ Only the postings that I make public.

$\square$ Both my public and my private postings.

$\square$ I would pick-and-choose posts from both my public and private postings. 


\section{Patient Questionnaire}

16) Recently, Facebook has been in the news for its use of personal data from Facebook Accounts through a company, Cambridge Analytica. Does this privacy violation make you more hesitant about:

your smartphone data being collected by the University of Pennsylvania?

$\square$ Yes $\quad \square$ No

sharing your smartphone data with your therapist (as part of a research study)?

$\square$ Yes $\quad \square$ No

sharing your social media with your therapist (as part of a research study)?

$\square$ Yes $\quad \square$ No

\section{If you don't have a smartphone, please skip \#17 and \#18, and turn over the page to continue the survey.}

17) Below is a list of information that a research app has the ability to collect from your smartphone. Please select the information that you would be okay with the app collecting. This information would be collected confidentially and shared only with professional researchers at the University of Pennsylvania.

Information collected using your phone's GPS:

Amount of time you spend at home

Amount of time during your day you spend not moving

Distance you travel

Maximum distance you travel from your home

Information collected by tracking how long your phone screen is on/off:

How long you sleep each day

Information collected about your communication:

Number of texts you send

Length of the texts you send

Number of texts you receive

Length of the texts you receive

Number of calls you make

Length of the calls you make

Number of calls you receive

How often you answer your phone

Length of the calls you receive

18) Would you be okay with your therapist also having access to that information?

$\square$ Yes $\quad \square$ No

